\title{
PENGARUH PELATIHAN TERHADAP KINERJA KARYAWAN PADA PT PDAM TIRTA PAKUAN KOTA BOGOR
}

\author{
Nancy Yusnita \\ Dosen Tetap Fakultas Ekonomi \\ Universitas Pakuan Bogor \\ Ratu Evo Rahdian \\ Mahasiswa Fakultas Ekonomi \\ Universitas Pakuan Bogor
}

\begin{abstract}
ABSTRAK
Penelitian ini dilakukan pada PT PDAM Tirta Pakuan Kota Bogor, sukasari 16142. Tujuan penelitian ini untuk mengetahui pelaksanaanpelatihan yang diterapkan dan untuk mengetahui bagaimana tingkat pelayanan karyawan pada PT PDAM Tirta Pakuan Kota Bogo, serta untuk mengetahui pengaruh pelatihan terhadap kinerja karyawan pada PT PDAM Tirta Pakuan Kota Bogor.

Jenis penelitian yang penulis gunakan adalah jenis verifikatif dengan metode penelitian explanatory survey. Jenis penelitian explanatory survey adalah metode yang bertujuan untuk menguji hipotesis, yang umumnya merupakan penelitian yang digunakan yaitu analisis koefesien korelasi, analisis koefesiensi determinasi, dan uji hipotesis koefesiensi korelasi.
\end{abstract}

Kata Kunci: Pengaruh pelatihan, Kinerja Karyawan

\section{Pendahuluan}

Pengembangan sumber daya manusia yang dilakukan melalui pelatihan mjerupakan suatu usaha untuk meningkatkan kualitas sumber daya manusia. Pelatihan merupakan hal yang sangat penting yang dapat dilakukan oleh organisasi tersebut memiliki tenaga kerja yang pengetahuan (knowledge), kemampuan (ability), dan keterampilan (skill)dapat memenuhi kebutuhan organisasi di masa kini dan dimasa yang akan datang.

Pada perusahaan yang penulis teliti di PT PDAM Tirta Pakuan Kota Bogor atau Perusahaan Daerah Air Minum merupakan salah satu unit usaha milik daerah, yang bergerak dalam distribusi air bersih bagi masyarakat umum. PDAM terdapat disetiap provinsi, kabupaten, dan kotamadya diseluruh Indonesia. PDAM merupakan perusahaan daerah 
sebagai sarana penyediaan air bersih diawasi dan dimonitor oleg aparat - aparat eksekutif maupun legislative daerah.

Sebagai perusahaan daerah yang dikuasai oleh pemerintah dalam menyediakan pasokan air bagi masyarakat dituntut untuk dapat melayani pelanggannya dengan baik, sehingga dibentuk loyalitas pelanggan. Namun loyalitas pelanggan belum menjamin bahwa PDAM telah memuaskan pelanggannya. Hal ini ditunjukan dengan adanya pelanggan yang kecewa atas pelayanan yang diberikan PDAM Tirta Pakuan Kota Bogor mulai dari air yang tiba - tiba tidak mengalir, terjadi kebocoran diberbagai saluran dan penyebab layanan yang mengakibatkan pasokan air menjadi terganggu.

Berdasarkan hasil wawancara terhadap salah seorang karyawan di PT PDAM Tirta Pakuan Kota Bogor, salah satu indikasi menurunnya kualitas kinerja karena banyaknya keluhan dari pelanggan atau konsumen. Keluhan tersebut antara lain: pelanggan atau konsumen harus mengunggu lama untuk pelayanan. Factor lamanya waktu tunggu tersebut diduga disebabkan kurangnya tanggung jawab yang ada pada diri karyawan tersebut dan kurangnya pelatihan yang efektif yang diberikan perusahaan terhapad karyawan, sehingga karyawan tidak dapat menyelesaikan pekerjaan sesuai waktu yang seharusnya.

Dalam ini perusahaan sangat tergantung terhadap alam dan tenaga kerja ahli. Selain itu dengan tidakadanya ketidak efektifan pelatihan yang berakibat menurunya kinerja karyawan. Sehingga hal ini menghambat proses pelayanan dan distribusi air bersih yang berlangsung diperusahaan dan akan berdampak pada kurangnya efektif dan efesien waktu. Oleh karena itu peneliti tertarik dengan permasalahan yang terjadi, dengan meneliti permasalahan tentang pengaruh pelatihan terhadap kinerja karyawan.

Sedabgkan tujuan penelitian ini adalah untuk mengetahui pengaruh pelatihan terhadap kinerja karyawan pada PT PDAM Tirta Pakuan Kota Bogor.

\section{Metode Penelitian}

Metode analisis yang digunakan dalam penelitian ini adalah:

1. Uji Validitas

Uji validitas dapat dilakukan dengan menghitung korelasi antara skor masing - masing item pertanyaan dengan total skor. Syarat suatu kuesoner dikatakan valid jika $r$ hitung $>r$ tabel dan tidak valid jika $\mathrm{r}$ hitung < $\mathrm{r}$ tabel. Dimana $\mathrm{r}$ tabel 0,361.

2. Uji Reliabilitas 
Uji reliabilitas yang digunakan dalam penelitian ini adalah metode internal. Metode internal dilakukan adalah melihat besarnya Croanbach Alpha ( $\mathrm{r}$ alpa) yang perhitungnyanya menggunakan prosedur Reliability Analysis pada pengaruh pelatihan terhadap program SPSS for windows versi 17.0. keputusan dan menentukan apakah instrumen yang ada telah reliable atau tidak reliable adalah :

1) jika $\mathrm{r}$ alpa positif dan lrbih besar $(>)$ dari batas minimal $(0,60)$ maka dinyatakan reliable.

2) jika $r$ alpa negative dan lrbih besar $(<)$ dari batas minimal $(0,60)$ maka dinyatakan tidak reliable.

3. Analisis Korelasi Rank Spearman

Untuk mengetahui kekuatan hubungan antara variabel $\mathrm{X}$ sebagai pengaruh pelatihan dan variabel Y sebagai kinerja karyawan. (Husein Umar, 2008: 112)

4. Analisis Koefisien Determinasi

Adalah setelah (r) diketahui maka untuk melihat sejauh mana kontribusi pelatihan terhadap kinerja karyawan maka dapat digunakan rumus berikut:

$\mathrm{Kd}=\mathrm{r} 2 \times 100 \%$

Dimana $: \mathrm{Kd}=$ coefecien determination presentase variabel pelatihan atau independensi terhadap persentase variabel kinerja dependen

$\mathrm{r}=$ koefeiensi korelasi, menunjukan tingkat keeratan pelatihan terhapad kinerja karyawan

5. Uji Hipotesis Koefisien Korelasi

Digunakan untuk menguji apakah hipotesis yang dibuat tersebut diterima atau tidak. Kriteria pengujian adalah Ho jika harga mutlak t dari rumus diatas lebih besar dari pada harga t yang didapat dari tabel distribusi dengan a yang dipilih.

\section{Hasil dan Pembahasan}

Untuk melihat adanya pengaruh pelatihan terhadap kinerja karyawan pada

PT PDAM Tirta Pakuan Kota Bogor maka dapat dilihat pada tabel berikut:

\subsection{Analisis Korelasi Rank Spearman}

Tabel 1.1

Ringkasan pengaruh pelatihan terhadap kinerja karyawan

\begin{tabular}{|l|l|l|lr|l|}
\hline Model & R & R Squer & Adjusted & R & Std Error of \\
\hline
\end{tabular}




\begin{tabular}{|l|l|l|l|l|}
\hline & & & Squer & the Estimate \\
\hline 1 & $.714(\mathrm{a})$ & .509 & .504 & .35765 \\
\hline
\end{tabular}

Dari hasil yang diperoleh dapat diintreprestasikan bahwa hubungan antara pengaruh pelatihan dengan kinerja karyawan adalah kuat dan positif, artinya semakin bagus dan baik pelatihan yang dilaksanakan maka kinerja karyawan akan semakin meningkat . hal tersebut diketahui bersadarkan tabel pedoman untuk memberikan interprestasi koefesien korelasi pada bab sebelumnya yang di mana nilai 0.714 berada di antara 0,16 - 0,799 yang berarti tingkat hubungannya adalah kuat.

\subsection{Analisis Koefisien Determinasi}

Dari tabel diatas dapay diketahu bahwa $r s=0,509$. Artinya pelatihan dengan kinerja karyawan mempunyai pengaruh yang sedang.

$$
\begin{aligned}
\mathrm{Kd} & =\mathrm{rs}^{2} \times 100 \% \\
& =0.509^{2} \times 100 \% \\
& =25,90 \%
\end{aligned}
$$

Hasil dari pelatihan tersebut pelatihan dapat mempengaruhi turun naiknya kinerja karyawan sebesar $25,90 \%$ sedangkan sisanya $74,1 \%$ dipengaruhi faktor lain diluar pelatihan.

\subsection{Uji Hipotesis Koefisien Korelasi}

\begin{tabular}{|c|c|c|c|c|c|c|}
\hline & & $\begin{array}{l}\text { Unstandardize } \\
\text { d Coeffcient }\end{array}$ & & $\begin{array}{l}\text { Standardized } \\
\text { Coeffcient }\end{array}$ & & \\
\hline Model & & B & $\begin{array}{l}\text { Std. } \\
\text { Error }\end{array}$ & & $\mathrm{T}$ & Sig. \\
\hline 1 & (constant & $\begin{array}{l}\text {,386 } \\
, 970\end{array}$ & $\begin{array}{l}, 389 \\
, 090\end{array}$ & ,714 & $\begin{array}{l}\text {,991 } \\
8,347\end{array}$ & $\begin{array}{l}, 324 \\
, 762\end{array}$ \\
\hline
\end{tabular}

Tabel 1.2

Koefisien Variabel X dengan Variabel Y 


\begin{tabular}{|l|l|l|l|l|l|}
\hline $\begin{array}{l}\text { Pengaruh } \\
\text { Pelatihan }\end{array}$ & & & & & \\
\hline
\end{tabular}

Uji t digunakan untuk mengetahui apakah pelatihan mempunyai hubungan yang positif atau tidak dengan kinerja karyawan.

Pengujian menggunkan tingkat signifikasi $\alpha=0,05$ (test sepihak) dengan derajat kebebasan df $=69-2=67$. Lamgkah - langkanya sebagai berikut:

1) Merumuskan hipotesis statistik

Ho: $r=0$ tidak terdapat pelatihan terhadap kinerja karyawan

Ha: $r>0$ terdapat hubungan nyata dan positif pelatihan terhadap kinerja karyawan

2) Mencari $r$ hitunng dan signifikansi

Dari out put coefficients variabel pengaruh pelatihan dengan variabel terhadap kinerja karyawan didapat t hitung sebesar 8,347 dan signifikansi 0,762

3) Mencari $r$ tabel

$\mathrm{T}$ tabel dapat dilihat pada tabel statistik pada signifikansi $\alpha=0,05$ dengan derajat kebebasan $\mathrm{df}=69-2=67$. Hasil yang diperoleh untuk t tabel sebesar 1,661.

4) kriteria pengujian

a. jika $r$ hitung $<\mathrm{t}$ tabel, maka Ho diterima dan Ha ditolak

b. jika $\mathrm{r}$ hitung $>\mathrm{t}$ tabel, maka Ho ditolak dan Ha diterima

5) Membuat kesimpulan

Karena $\mathrm{r}$ hitung $>\mathrm{t}$ tabel $(8,347>1,661)$, maka Ho ditolak dan Ha diterima. Jadi dapat disimpulkan bahwa pelatihan mempunyai hubungan yang nyata dan positif terhapad kinerja karyawan pada PT PDAM Tirta Pakuan Kota Bogor.

\section{Kesimpulan}

Kesimpulan yang dapat ditarik dari penelitian ini mengenai Pengaruh Pelatihan Terhadap Kinerja Karyawan Pada PT PDAM Tirta Pakuan Kota Bogor, adalah sebagai berikut:

a. Jurnal sampel yang digunakan 69 responden

b. Jenis penelitian ynag digunakan adalah verifikatif 
c. Metode yang digunakan adalah metode analisis analisis koefesien korelasi, analisis koefesiensi determinasi, dan uji hipotesis koefesiensi korelasi.

d. Berdasarkan dari analisis analisis koefesien korelasi diperoleh rs $=0,714$. Angka tersebut menunjukan hubungan antara pelatihan dengan kinerja karyawan memiliki tingkat hubungan yang kuat.

e. Berdasarkan dari analisis koefesiensi determinasi diperolek $\mathrm{kd}=50,9 \%$ hal ini menunjukan bahwa pelatihan menentukan turun naiknya kinerja karyawan PT PDAM Tirta Pakuan Kota Bogor 20,90\% dan saelebihnya 74,1\% dipengaruhi faktor lain.

f. Berdasarkan dari analisis uji hipotesis koefesiensi korelasi di peroleh t hitung $(8,347)$ $>\mathrm{t}$ tabel $(1,661)$ Ho ditolak dan Ha diterima. Jadi dapat disimpulkan bahwa pelatihan mempunyai hubungan yang nyata dan positif terhapad kinerja karyawan

\section{Daftar Pustaka}

A.A Anwar Prabu Mangkunegara, Drs. 2000, Manajemen Sumberdaya Manusia. Remaja Rosda Karya. Bandung

Bangun, Wilson, 2012. Manajemen Sumber Daya Manusia. Erlangga. Bandung

Byan And Rue, 2008. Panduan Praktis Mengelola Pelatihan. Cetakan 1. EDSA Mahkota. Jakarta

Sugiono. 2009. Metode Pelatihan Administrative Dilengkapi Dengan Metode R\&D. Alfa Beta. Bandung

Benardin, 2001. Manajemen Personalia. Cetakan Ke 1. Umm Press. Malang. 